\title{
Local Specialty Food as Tourism Potential
}

\author{
Anak Agung Gede Putra KP Dalem \\ Politeknik Pariwisata Bali, Jln. Darmawangsa, Kampial, Benoa, Kuta Selatan, Badung, \\ Indonesia \\ *Corresponding Author. E-mail: dalemputrabali@gmail.com
}

\begin{tabular}{|c|c|}
\hline \multicolumn{2}{|l|}{ ABSTRACT } \\
\hline \multirow{2}{*}{\multicolumn{2}{|c|}{$\begin{array}{l}\text { Food is one of the cultures of a region that can be enhanced to become a tourist attraction. } \\
\text { However, due to a lack of community understanding, they are unable to understand this potential, } \\
\text { so there is no data for conservation, and they continue to allow young people to be carried away } \\
\text { by the flow of modernization, particularly in the introduction of local specialties. On the other } \\
\text { hand, the trend of tourists visiting on tourist destination is due to its unique local food that cannot } \\
\text { be found anywhere else. For this reason, tourism supporters that must be visited and cannot be } \\
\text { brought home are the local specialties of an area that is a tourist visit area, in addition to the loss of } \\
\text { identity and one of the assets that can be used as a tourist attraction. } \\
\text { Keywords: culinary, local specialty food, gastronomy, tourism }\end{array}$}} \\
\hline & \\
\hline First Received: April 2021 & Accepted: June 2021 \\
\hline Final Proof Received: June 2021 & Published: June 2021 \\
\hline
\end{tabular}




\section{Introduction}

Culinary tourism has recently undergone many developments. The current trend of tourists coming to a tourist area is not just wanting to enjoy the beauty of the surrounding nature but also hunting for local food from the area itself. The tourists who come do not hesitate to spend more money to taste new foods. Good processing of food to be beneficial to the body Local food, which can be defined in various ways. Local specialties, according to Marwanti (2000), are stapled foods that become daily food, either in the form of snacks or special dishes, or have been passed down from generation to generation according to their ancestors. Local food, also known as culinary, is a type of food that is closely related to a region and is passed down from generation to generation as part of tradition (Jordana, 2000).

Local food or culinary is a type of food that is closely related to an area and is passed down from generation to generation as part of tradition (Pieniak, et al 2009). Local food typical of regions in Indonesia has existed for a long time and still survives to this day so it is highly valued as a cultural heritage. The recipes used have also been passed down from generation to generation, even the way to cook it is still using the old way.

Indonesia has many islands and thirty-four provinces, each with its special food that is usually consumed and served as part of ceremonies and is made from natural ingredients as well as the method of preparation. It is hoped can be maintained and preserved for future generations. However, with the rise of modern foods, the local foods that had become the identity began to shift. Modern food is regarded as more prestigious than traditional local foods.

Indonesia has a wide range of regional specialties with a strong flavor of spices or herbs. A side from natural beauty, typical local food plays an important role as a tourist attraction in and of itself, particularly for tourists seeking experiences rather than the local specialties served.

The increasing number of tourists visiting and the highest percentage lies in the length of stay of tourists for 2-3 days, it is hoped that tourists have tasted some of the local specialties served, and the results of this percentage can be used as a reference in marketing in introducing various kinds of food local specialties, raising uniqueness is very important if it is associated with tourism because "tourism is different" (Sukerti, 2016).

There is no reference or documentation related to local food that can also become community knowledge about how local food development is going. This is done as the first step toward preserving local culinary traditions. Making an inventory of local food is one of the efforts that can be made.

According to Sugiama (2013), asset inventory is a set of activities that includes funding, recording, reporting the results of asset data collection, and documenting both tangible and intangible assets at a given time. The results of a local specialties inventory can be used to identify food potential in a specific area to improve and promote local food development.

This paper is an early-stage form that will be used as reference material for further research that will concentrate on the inventory of local foods, especially those found in tourist destinations, and will then be documented. This paper is expected to be used as a means to identify the potential of food in each region to improve and promote the development of local food typical of each region.

\section{Materials and Methods}

2.1 Variety and Kinds of Local Food

Food and drink are inextricably linked to a society's traditions. As a result, food and drink have a local phenomenon that 
concerns the culture of the local community, so the food and drink in the area is referred to as typical food or traditional food, namely food (including snacks) and drinks, as well as mixed ingredients (ingredients) passed down from generation to generation. It has been used and developed in specific areas or communities (Indrati and Gardjito, 2014).

In general, traditional foods are made from recipes already known to the local community, with ingredients sourced locally, and have a flavor that appeals to the tastes of the local community. According to Indriati and Gardjito (2014), traditional foods are classified into four categories:

a. The main food is the type of food that is a menu staple, made in large quantities and is especially shown to alleviate hunger. The main food is a source of energy for the body, so the type of food is carbohydrate-containing foods like rice, corn rice, and processed cassava.

b. A side dish is a type of food that is served alongside the main course and is intended to grow and increase appetite. Soupy and non-gravy side dishes, fried and grilled, steamed and boiled, and sambal-sambal are all options. Side dishes are classified as either vegetable or animal based on their basic ingredients.

c. Snack or snack market food, also known as street food, is a type of food consumed throughout the day as a distraction, enjoyment, and entertainment that is not restricted by time, place, or amount consumed. Snacks have been shown to not only reduce hunger but also to add food substances that are not present or are lacking in main meals and side dishes.

d. Beverage, either cold (ice, syrup) or hot, serves to quench thirst or to provide pleasure and satisfaction (soft drink), such as tea, coffee, bandrek, wine, or palm wine).

Food is classified into three types, according to Bujang (1995):

a. Main food, that is, food that is required to meet biological needs and to exist daily.

b. Side food is food that is consumed as a supplement to the main meal rather than as a source of nutrition.

c. Special food, that is, food provided by people in response to the circumstances, events, and times when such food is required, such as food for social and religious ceremonies, food in an emergency, and food during the month of fasting, and so on.

Food Functions and Applications

Food serves and is used for the following purposes:

a. The function of food is to provide heat and energy to the body, build new body tissues, maintain and repair old ones, regulate natural and chemical processes in the body (Anwar, 1989).

b. The use of food in the body is to provide food for work, for body growth, protect the body against various diseases, regulate body temperature, and form food reserves in the body (Anwar, 1989).

\subsection{Food Selection Influencing Factors}

According to Indrati and Gardjito (2014), several factors influence the food and drink consumed by humans obtained from the environment where the group lives. One of the manifestations of human culture is food which is in the process of processing from raw materials into food, as well as its manifestation, ways of presentation, and consumption are influenced by several factors, including:

a. Physiological and Psychological Factors

b. Physical and psychological factors distinguish humans from their need for food, including the meaning of food in each individual. Hunger and thirst are physiological signs that the body tells the brain that our body needs food that must be acted upon immediately. Taste is a psychological impulse that appears unexpectedly.

c. Religion, Culture, and Society Factors

d. Religious factors, ethics, and one's 
beliefs will also affect the habits, ways, and factors of choosing what food to consume. For example in Muslim communities, generally they do not eat pork and do not want to drink alcohol because it is forbidden by their religion. Cultural factors or traditions that have been attached from generation to generation in certain communities can also influence the pattern of their food habits. Balinese people generally have the habit of eating three times a day, namely breakfast, lunch, and dinner with the same menu, while the people choose food based on the symbiotic value compared to the nutritional value of the food and condition factors such as nature and the availability of food in an area. Greatly affect of consumption patterns and eating habits of the area. The availability of food depends on climatic conditions, changes in weather, and methods of farming, food production, transport, and availability of technology levels.

\subsection{Food Commodities}

Food science is the study of the properties and chemistry of the components found in animal and vegetable foodstuffs, including the nutritional value of these foodstuffs, and how these properties relate to production and treatment before and after harvest. Food or food is anything derived from biological sources and water, both processed and unprocessed, that is intended for human consumption as food or drink. This includes food raw materials, food additives, and other materials used in the preparation, processing, and production of food and beverages (Indrati and Gardjito, 2014).

Suhardjo (1988) defines food as "material that is consumed daily to meet the needs for maintenance, growth, work, tissue replacement, and the regulation of processes in the body." Food commodities are commercial goods obtained from biological crops and water, both processed and unprocessed, that are used as food or drinks for humans, can also meet nutritional needs and can become a source of energy to carry out daily activities, according to the above definition. -today.

According to Indrati and Gardjito (2014), food ingredients are divided into two categories: fresh food and processed product. Food, according to Moertjipto (1993), is the result of the processing of a food ingredient obtained from agricultural, plantation, fishery, and technological products. Food can be classified into three types based on how it is obtained, according to Saparinto and Hidayati (2006):

a. Fresh food, namely food that has not undergone processing that can be consumed directly or indirectly (raw material for food processing), for example bananas and so on.

b. Food that has been processed in a specific way or method, with or without the addition of additional ingredients. Processed foods are further subdivided into ready-to-eat processed foods and unprepared processed foods.

- Ready-to-eat processed food is food that has been processed and is ready to be served at the place of business or outside the place of business on an order basis, for example fried bananas and so on.

- Processed food that is not ready to eat is food that has undergone a processing process but still requires further processing steps to be eaten or drunk, for example, canned food and so on.

c. Certain processed foods are processed foods intended for specific groups to maintain and improve health quality, such as low-fat milk for people on a fat diet, and so on.

\section{Results and Discussion}

Gastronomy is an increasingly popular term, but theoretically, it is still difficult to define. From the root word, "gastronomy" comes from ancient Greek, namely gastro which means 'stomach or stomach' and nomos which means 'law or 
rule'. Experts generally associate the term gastronomy with terms such as culinary, culinary arts, and culinary arts, although gastronomy is also believed to have a wider scope of meaning, namely as all forms of study and appreciation of food and beverages.

Gilleisole (2001:235) defines gastronomy as the art or science of good eating practices. According to another definition, gastronomy also includes everything related to the enjoyment of food and drink. Meanwhile, gastronomy is defined as knowledge of anything related to the fulfillment of human food in The Physiology of Taste, as explained by Brillat-Savarin (1949:96) as follows: "Gastronomy is the intelligent knowledge of whatever concerns man's nourishment."

According to Brillat-Savarin (1949), gastronomy contains at least five main elements:

a. sight (which is visible), what is seen by the eye is the initial determinant of a person's interest in enjoying a food;

b. Hearing (which is heard with the ear), the ear can hear a crisp sound when food is consumed or hear the ongoing cooking process, such as in open kitchens and restaurants that show consumers the process of making food;

c. smell (which can be smelled with the nose), the nose can smell the distinctive aroma of food when it is cooked or served;

d. taste (which is felt on the tongue), namely the tongue's ability to determine whether the food is delicious or by the taste of the person tasting it; and

e. touch (as perceived by the hands), namely, a person's ability to feel the temperature and texture of food with his hands.

Furthermore, gastronomy as a science includes in-depth knowledge of national foods and beverages from various major countries around the world. In this case, gastronomy can serve as a foundation for understanding how food and drink are used in specific situations. Gastronomy can help to paint a picture of the similarities and differences in approaches or behaviors toward food and beverages used in different countries and cultures.

Many academics also emphasize the close relationship that exists between human culture and food in various gastronomic senses. In this case, gastronomy is viewed as a study of the relationship between culture and food, with gastronomy studying various aspects of culture with food as the focal point. This relationship exists because gastronomy is essentially a product of agricultural activities, so the embodiment of color, aroma, and taste of a food can be traced back to its origins in the environment where the raw materials are produced (Taqwani, 2012: 55)..

Aside from the term gastronomy, the more common culinary terms are also known. The distinction between these two terms is found in the term gastronomy, which encompasses the evolution of consumption patterns and eating culture (Alamsyah, 2008:1). Meanwhile, culinary is defined as an activity that prioritizes local food as its object and creates new experiences through traditional flavors, spice uses, and packaging (Elizabeth, 2016:16). The process of creating, serving and consuming them. According to the definitions of the two terms, culinary refers to food as a physical product (tangible) that can fulfill needs while providing a pleasant experience for those who consume it, whereas gastronomy includes not only physical products but also intangible values, containing food products, including the manufacturing, serving, and consumption processes.

Food is one of the three primary needs of humans. Food, according to the Indonesian Ministry of Health (2000), is all processed ingredients consumed by humans, excluding water and medicines. Permenkes No. 329 of 1976 defines food as goods used as human food or drink, including chewing gum and the like, but not medicine. Food is necessary for growth because it contains the materials required to build and replace body 
tissues, to maintain the body's defenses against disease, and to provide energy for work.

Meanwhile, Fahmal (2006) defines local as "a place or in a place or in a place where there is growth, life, something that is different from other places or is in a place of value that may apply locally or may also apply universally." This local boundary is concerned with geographical aspects such as residence or ethnicity, a city or a village (Abdullah, 1985). According to the Big Indonesian Dictionary, local means "in one place, uneven, local, somewhere" (about making, producing, growing, living, and so on).

According to Shenoy (2005), local culinary is a fundamental component in a destination, adding to the attraction and tourist experience. The local cuisine has a great opportunity to develop, one of which is because tourists who care about local culture and heritage consider local culinary to be one way to get to know local heritage and culture (Sims, 2010). A gastronomy tourism design program is involved several stakeholder, such as some residents, scholars, local and foreign tourists, and its government (C. Ningsih, et.al, 2021).

\section{Conclusions}

Based on the description above, it is clear how distinct local specialties define a region. Identifying an area as a local uniqueness is a tourist attraction. The intensify empowerment of local food in an area, especially those with distinctive characteristics, will be able to create a tourist attraction based on local culture and maintain its identity while supporting the economic activity in an area.

\section{References}

No. 329/Menkes/Per/XII/1976/tPdPM.

Abdullah, Taufik. (1985). Ilmu Sejarah dan Histografi. Jakarta: Gramedia.

Anwar Asrul. 1989. Pengantar Ilmu Kesehatan Lingkungan. Mutiara Jakarta.
Arikunto, S. 2002. Metodologi Penelitian Suatu Pendekatan Proposal. Jakarta: PT Rineka Cipta.

Brillat-Savarin, J. A. (1949). Gastronomy is the intelligent knowledge of whatever concerns man's nourishment. The Gastronomic Servings of Brillat-Savarin. Washington Times.

C. Ningsih, et.al. (2021), Gastronomy Tourism Development Model on a Tourist Village. Book of Promoting Creative Tourism: Current Issues in Tourism Research. Routledge. p. 476-481

Bujang, Ibrahim. 1995. Wujud Variasi dan Fungsinya Serta Cara Penyajiannya pada Orang Melayu, Jambi. Jakarta: Departemen Pendidikan dan Kebudayaan.

Indrati, R. dan Gardjito, M. 2014. Pendidikan Konsumsi Pangan: Aspek Pengolahan dan Keamanan. Jakarta: Kencana Prenada Media.

Irawan, Prasetya. 2006. Penelitian Kualitatif dan Kuantitatif Untuk Ilmu-Ilmu Sosial. Departemen Ilmu Administrasi FISIP UI.

Jordana J. 2000. Tradisional Food: Challenges Facing the European Food Industry. Food Research International.

Marwanti, 2000. Pengetahuan Makanan Indonesia.Adicita Karya Nusa, Yogyakarta.

Moertjipto, J.S. 1933. Makanan, Wujud, Variasi dan Fungsinya Serta Cara Penyajianya Pada Orang Jawa Daerah Istimewa Yogyakarta. Depdikbud Direktorat Sejarah dan Nilai Tradisional Proyek Penelitian Pengkajian dan Pembinaan Nilai-nilai Budaya. Yogyakarta

Mukhtar. 2013. Metode Praktis Penelitian Deskriptif Kualitatif. Jakarta: GP press Group.

Saparinto, Cahyo dan Hidayati. 2006. Bahan Tambahan Pangan. Yogyakarta: KANISIUS (Anggota IKAPI)

Shenoy, Sajna S. 2005. Food Tourism And 
The Culinary Tourist. Thesis. Clemson University.

Sugiama, A. G. 2013. Metode Riset Bisnis dan Manajemen. Edisi Pertama, Bandung: Guardaya Intimarta.

Sugiyono. 2003. Metodologi Penelitian. Bandung: Alfabeta.

Sugiyono. 2010. Metode Penelitian Pendidikan Kuantitatif, Kualitatif, dan $R \& D$. Bandung: Alfabeta.

Sugiyono. 2014. Metode Penelitian Kualitatif Kuantitatif dan $R \& D$. Bandung: Alfabeta.

Suhardjo, Hardiansyah dan Riyadi, H. 1988. Survei Konsumsi Pangan, PAU Pangan dan Gizi. IPB. Bogor.

Sukerti, dkk. 2016. Reinventarisasi Makanan Tradisional Buleleng Sebagai Upaya Pelestarian Seni Kuliner Bali. Bali, 1 April 2016.

Winartha, Made. 2006. Metodologi Penelitian Sosial Ekonomi. Yogyakarta: Andi Offset

Wirartha. 2006. Pedoman Penulisan Usulan Penelitian, Skripsi dan Tesis. Yogyakarta: Andi. 